\title{
Pengelolaan Beras Organik: Persediaan dan Permintaan
}

\author{
Stephana Dyah Ayu Ratnaningsih ${ }^{\# 1}$, Stefani Lily Indarto ${ }^{* 2}$ \\ \#Akuntansi, Universitas Soegijapranata \\ Jl. Pawiyatan Luhur IV/1 Bendan Dhuwur Semarang \\ 1stephana@unika.ac.id \\ ${ }^{2}$ sli@unika.ac.id
}

\begin{abstract}
Abstrak-Peningkatan kesadaran kesehatan menyebabkan permintaan bahan pangan organik meningkat. Pengelolaan pertanian organik menjadi hal yang perlu diperhatikan untuk menjaga ketersediaan kebutuhan ini. Pengabdian yang dilakukan bertujuan untuk membantu kelompok petani di kota Salatiga yang menjadi mitra pengabdian agar dapat memperbaiki pengelolaan persediaan produk hasil pertanian yang akan dijual. Lingkup yang menjadi fokus dalam pengabdian in adalah produk unggulan mereka yaitu beras hitam organic, beras merah organic, beras pandan wangi dan beras mentik susu. Meskipun lebih sehat, bahan pangan kurang popular di kalangan petani. Hal ini disebabkan karena sulitnya penerapan pertanian organic, dan produk yang dinilai lebih rapuh dibandingkan dengan produk non-organik. Komplain yang muncul mengeni munculnya kutu atau jamur pada beras organic merupakan masalah yang dihadapi kelompok tani dalam pemasaran beras organic. Metode pengabdian yang dilakukan terdiri dari dua tahapan utama. Pada tahap pertama tim pengabdian mendampingi kelompok tani dalam mengkoordinasikan pengujian ketahanan pangan terhadap produk - produk utama. Hasil pengujian ketahanan pangan sangat mempengaruhi kebijakan yang diambil dalam melakukan pengelolaan produk. Pada tahap kedua tim pengabdi memberikan pelatihan dalam perumusan kebijakan yang bisa diambil untuk mengatasi hambatan yang teridentifikasi dalam pengelolaan persediaan hasil pertanian organik pada kelompok tani ini. Hasil dari pengabdian ini adalah kebijakan penetapan umur simpan beras yang sebelumnya tidak diperhatikan dalam pengelolaan persediaan. Pada pengabdian ini kelompok tani juga melakukan simulasi penerapan aplikasi e-farming untuk memeberikan gambaran bagaimana keterkaitan pengelolaan persediaan dengan proses penjualan dan distribusi.
\end{abstract}

Kata kunci-pertanian, pangan, organik, beras, persediaan

Abstract-Increased health awareness causes the demand for organic food to increase. Organic farming management is something that needs to be considered to maintain the availability of this need. The service carried out aims to help farmer groups who become service partners in order to improving management of agricultural products. The scope of focus in this service is their superior products, namely organic black rice, organic brown rice, fragrant pandan rice and mentik milk rice. Although it is healthier, it is less popular among farmers. This is due to the difficulty of implementing organic farming, and products that are considered more fragile than non-organic products. Complaints that arise regarding the appearance of lice or fungi in organic rice are a problem faced by farmer groups in marketing organic rice. The method of devotion carried out consists of two main stages. In the first stage, the service team accompanies farmer groups in coordinating food durability testing for main products. The results of food security testing greatly affect the policies taken in managing the product. In the second stage, the community service team provided training in the formulation of policies that could be taken to overcome the barriers identified in the management of organic agricultural products in this farmer group. The result of this community service is the policy of determining rice time storage which was not considered in inventory management before. In this community service, farmer groups also simulate the application of e-farming applications to provide an overview of how inventory management is related to the sales and distribution process.

Keywords - agriculture, food, organic, rice, inventory

\section{PENDAHULUAN}

Ketahanan pangan merupakan salah satu prioritas utama pemerintah Indonesia. Pemenuhan kebutuhan pangan merupakan standar minimal terwujudnya pembangunan yang berkelanjutan yang dicanangkan dalam Sustainibility Development Goals (SDGs) 2030 yang disepakati oleh negara - negara yang PBB [1]. Bagi bangsa Indonesia yang makanan pokonya adalah beras perhatian terhadap terpenuhinya kebutuhan beras menjadi salah satu perhatian utama. Salah satu kebijakan yang banyak ditempuh untuk memenuhi kebutuhan tersebut adalah melakukan impor beras. Tingkat produksi beras merupakan salah satu penentu impor beras pemerinta, selain factor - factor lain seperti tingkat konsumsi beras, harga beras dalam negeri dan nilai tukar rupiah terhadap dollar AS [2]. Oleh karena itu, 
peningkatan produksi beras pada pertanian dalam negri menjadi hal yang penting untuk dilakukan.

Peningkatan terhadap produksi beras organik merupakan hal yang bijak untuk dilakukan karena adanya pengingkataan kesadaran terhadap kesehatan. karena pengeaitan Pengkatan permintaan terhadap bahan pangan organic di masyarakat menjadi celah yang yang harus diisi oleh para petani Indonesia [3]. Kemampuan untuk mengaitkan penyediaan kelompok tani dan konsumen penting di masa sekarang [4]. Beras organik memberi tantangan yang lebih besar dalam pengadaannya karena adanya tuntutan akan kualitas tanah yang lebih baik [5]. Pengelolaan persediaanya juga menjadi hal yang penting untuk diperhatikan [6], Tulisan ini difokuskan pada bagaimana peningkatan pengelolaan persediaan pada kelompok tani di Salatiga ini. Kegiatan pengabdian ini dilakukan pada kelompok tani Al-Barokah yang merupakan kelompok petani yang menggerakan perteanian organic di wilayah Salatiga.

\section{METODE}

Metode pengabdian yang dilakukan terdiri dari dua tahapan utama.

\section{A. Tahap 1 : Uji Ketahanan Pangan}

Pada tahap pertama tim pengabdian mendampingi kelompok tani dalam mengkoordinasikan pengujian saing perusahaan.[8]

\section{PEMBAHASAN} lain.

Hasil yang diperoleh dalam proses pengabdian ini antara

\section{A. Pengujian Produk}

Pada tahap pertama berasa hasil produksi diuji sesuai dengan kemasannya. Pada umunya kelompok tani di Indonesia ketiaka memasarkan hanya membagi kemasan beras hanya berdasarkan beratnya. Kemasan yang biasa dipergunakan adalah dengan menggunakan kemasan $5 \mathrm{~kg}$, $10 \mathrm{~kg}$ dan $25 \mathrm{~kg}$ [9]. Akan tetapi pada kelompok tani Salatiga ini kemasan yang yangpaling banyak digunakan untuk produk beras organik adalah yang kemasan $5 \mathrm{~kg}$. Hal ini karena mempertimbangkan harga yang cukup mahal. Sehingga kemasan yang kecil dianggap lebih menjual.

Dalam proses ini pengujian dilakukan bekerjasama dengan Laboratorium Pangan Unika Soegijapranata Semarang. Pada tahap pengujian ini diuji beberapa jenis beras sekaligus. Selain itu ada dua kemasan yaitu kemasan yang kedap dan kemasan biasa. Hasil pengujian menunjukan bahwa beras organik lebih tidak tahan lama disbanding beras non-organik. Meskipun demikian, hal ini ketahanan pangan terhadap produk - produk utama. Pada tahap pengujian ini terutama diuji adalah pembedaan kemasan yang dipergunakan Hasil pengujian ketahanan pangan akan mempengaruhi kebijakan yang diambil dalam melakukan pengelolaan produk.

\section{B. Tahap 2 : Pengelolaan Persediaan}

Pada tahap kedua tim memfokuskan pada perbaikan yang dapat dilakukan pada kelompok tani yang menjadi mitra pengabdian. Pada tahapan ini dilakukan terlebih dahulu identifikasi terhadap kelemahan - kelemahan yang terjadi pada pengeloaan pertanian kelompok tani ini. Kegiatan itu dilakukan dalam forum group discussion ( $F G D$ ) bersama para pengurus kelompok tani. Kegiatan ini dilakukan dengan menggunakan panduan pertanyaan yang bersifat open-ended. Penggunaan perangkat pertanyaan open-ended diharapkan tidak akan membatasi informasi yang diberikan oleh partisipan ${ }^{[1]}$. [7]. Kegiatan ini diharapkan dapat dilagunakan untuk menjadi media berdiskusi untuk tidak sekedar melakukan identifikasi terhadap permasalahan yang ada namun juga mencari solusi yang dianggap feasible. Pada akhir tahap kedua dilakukan pelatihan pengelolaan persediaan dengan menggunakan aplikasi. Penggunaan aplikasi akan lebih membantu pelaksanaan pengelolaan persediaan [6]. Pelatihan kedua dilakukan dengan menggunakan program ERP. ERP dianggap mampu untuk meningkatkan daya

bisa diatasi dengan menggunakan kemasan vakum. Kemasan vakum ini terbukti bisa membuat daya simpan beras bertahan cukup lama.

\section{B. Pengelolaan Persediaan}

Kegiatan diskusi Bersama kelompok tani dilakukan pada tahap kedua. Hasil forum group discussion (FGD) bersama para pengurus kelompok tani dilakukan identifikasi terhadap permasalahan pengelolaan persediaan yang dihadapi. Hasil penelaahan terhadap permasalahan yang diiidentifikasi menemukan bahwa permasalahan yang ada dapat dikerucutkan pada dua focus pengelolaan persediaan. Dalam diskusi ini juga dibahas bagaimana kebijakan yang sebaiknya diambil

Fokus pertama pada pengelolaan persediaan adalah aliran barang. Permasalahan pertama yang diidentifikasi adalah adanya keterbatasan produk organic yang tidak memiliki daya tahan yang lama. Permasalahan kedua yang diidentifikasi terkait dengan pengelolaan persediaan adalah pemerataan produk yang dijual antar petani yang menjadi anggota tani. Hal ini muncul karena lemahnya pencatatan yang dilakukan oleh pengelola. Transparansi merupakan salah satu cara untuk menghindari kecurangan [10] Peningkatan transparansi terhadap pengelolaan dapat 
dilakukan dengan penyelenggaraan pencatatan terhadap aliran barang yang ada.

Secara umum dalam pengelolaan persediaan secara kauntansi dapat dikenal ada beberapa metode yaitu First In First Out (FIFO), Last In First Out (LIFO) dan Average [11]. Ketiga metode masing - masing memiliki keuanggulan kelemhan masing masing . Hasil diskusi menemukan bahwa metode FIFO dianggap menjadi pilihan yang paling tepat untuk digunakan. Penggunaan metode FIFO dipilih setelah mempertimbangkan batasan umur simpan beras organik. Penggunaan metode ini diharapkan akan mengurangi potensi barang rusak. Hal ini juga sesuai dengan penelitian yang telah dilakukan sebelumnya yang menemukan bahwa penggunaan metode FIFO juga dianggap paling memberikan keuntungan dibandingkan metode yang lain [2]. Model pencatatan ini juga diharapkan akan meningkatakan keadilan dalam pemasaran. Supaya tidak hanya prodak petani tertentu saja yang mendominasi atau mendapatkan prioritas. Dengan demikian kebijakan ini akan meningkatkan kepercayaan para anggota kelompok tani kepada pengelola. Penyelenggaraan pencatan yang tepat membutuhkan dukungan system informasi yang memadai [12]. Penggunaan ERP dapat membantu pengelolaan persediaan [6], [13].

Fokus kedua dalam pengelolaan persediaan adalah terkait dengan masalah kemasan. Hasil dari FGD yang dilakukan mengidentifikasi adanya beberapa kelemahan dalam kemasan yang ada. Hal ini berdasarkan pengalaman yang mereka alami yaitu ada perusahaan yang melakukan pengemasan ulang terhadap produk mereka. Perusahaan tersebut mampu menjual dengan harga yang jauh lebih mahal dibandingkan dengan harga yang biasa gunakan oleh petani Ketika menjual ke petani. Adanya pengujian terhadap umur simpan beras yang sudah dilakukan pada tahap pertama dapat membantu mereka untuk mencantumkan tanggal kadaluarsa. Hal ini sesuai dengan penelitian yang pernah dilakukan Syamsudin dkk sebelumnya yang membuktikan bahwa desain kemasan, pencantuman nama produk, berat produk yang dijual dan pencantuman tanggal kadaluarsa terbukti mampu untuk meningkatkan pemasaran produk - produk organic [14]. Hasil diskusi kemudian juga merumuskan kebijakan untuk memprioritaskan penggunakan kemasan vakum $5 \mathrm{~kg}$ untuk melakukan pemasaran. Sesuai hasil oengujian tahap pertama diketahui bahwa kemasan vakum dianggap lebih tahan lama dibandingkan non vakum. Selain itu penggunakan kemasan vakum dianggap memiliki nilai estetika yang lebih baik.

Gambar 1. Diskusi Kebijakan Pengelolaan Persediaan

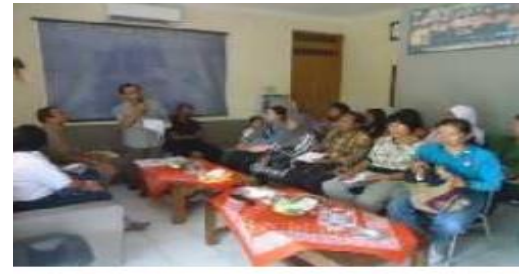

\section{Pelatihan ERP}

Pengelolaan persediaan pertanian dapat lebih baik dilakukan dengan menggunakan model ERP [6]. Pada tapak kedua pengelolaan persediaan ini selain kegiatan FGD adalah dengan melakukan simulasi pengelolaan persediaan dengan menggunakan aplikasi berbasis web yang bernama www.farming.accounting.net. Aplikasi ini merupakan sistem sederhana yang dapat digunakan untuk pengelolaan persediaan. Dengan menggunakan bantuan aplikasi ini setiap anggota dalam kelompok tani ini dapat saling terhubung. Dengan demikian pengelolaan selain lebih transparan juga dapat lebih tertelusur pencatatannya. Model pelatihan dengan menggunakan aplikasi dipilih karena model pelatihan ini diharapkan dapat lebih mensimulasikan bagaimana keterkatian antar para anggota dan pengurus. Para pengelola dan wakil anggota kelompok tani yang mengikuti pelatihan cukup mendapatkan pmahaman mengenai ERP dalam pengelolaan persediaan.

Gambar 2. Pelatihan ERP

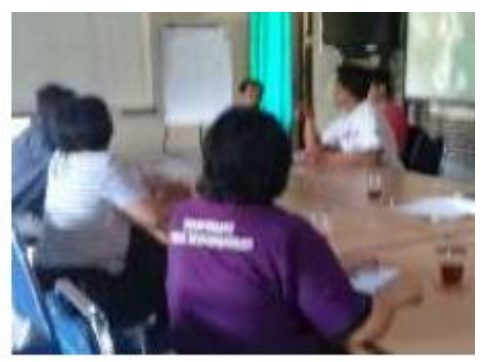

\section{IV.PENUTUP}

\section{A. Simpulan}

Pertanian yang maju tidak hanya memperhatikan proses pengelolaan tanaman yang ada, namun juga memperhatikan bagaimana pengelolaan hasil pertanian. Hasil pengujian terhadap umur simpan beras organic menunjukan tingkat ketahanan pangan yang lebih rendah disbanding beras non organi, Oleh karena itu pengelolaan persediaan menjadi salah satu hal yang penting bagi produk beras organik. Penggunaan metode FIFO yang didukung dengan keberadaan ERP akan diharapkan akan meningkatkan produktivitas petani. Metode pengemasan menjadi salah satu alternatif yang menjadi fokus. Penggunaan aplikasi 
menjadi salah satu sarana yang dapat digunakan untuk membantu pengelolaan tersebut.

\section{B. Saran}

Pengabdian kepada kelompok petani dapat lebih dikembangkan di masa yang akan datang. Kegiatan pengabdian dapat dikembangkan pada bagaimana strategi pencapaian sertifikasi. Selain itu diharapkan juga pengabdian dimasa yang akan dating dapat dikembangkan untuk lebih mengkaitkan kelompok tani dengan para konsumennya. Hal ini akan sangat membantu pemasaran.

\section{DAFTAR PUSTAKA}

[1] J. D. Moyer and S. Hedden, "Are we on the right path to achieve the sustainable development goals?," World Dev., vol. 127 , p. 104749,2020

[2] N. Y. K. Pratiwi, E. A. Lau, and Heriyanto, “Analisis Penilaian Persediaan Beras Terhadap Perolehan Laba Pada PT . Indogrosir Samarinda," J. Indones. Sci. Econ. Res., vol. 2, no. 3, pp. 18-25, 2020.

[3] L. R. J. Pangemanan and C. R. Ngangi, "Analisis Kepuasan Konsumen Terhadap Atribut Sayuran Organik Di Hypermart Manado," Cocos, vol. 6, no. 14, 2015.

[4] S. L. Indarto, S. D. A. Ratnaningsih, and S. M. D. Endah, Digitalisasi CRM: Linking Customer-Farmer. Yogyakarta: Kepel Press, 2019.

[5] A. Yuniarti, E. Solihin, and A. T. Arief Putri, "Aplikasi pupuk organik dan N, P, K terhadap $\mathrm{pH}$ tanah, P-tersedia, serapan P, dan hasil padi hitam (Oryza sativa L.) pada inceptisol," Kultivasi, vol. 19, no. 1, p. 1040, 2020.

[6] S. L. Indarto, S. D. A. Ratnaningsih, and S. M. D. Endah, Efektivitas Kinerja Melalui Pemanfaatan Enterprise Resource Planning (ERP) dan Customer Relationship Management (CRM). Yogyakarta: Amara Books, 2018.

[7] J. Creswell, Riset Pendidikan:Perencanaan,Pelaksanaan dan Evaluasi Riset Kualitatif dan Kuantitatif, I. Yogyakarta: Pustaka Pelajar, 2015.

[8] M. Nawawi and D. Yunia, "Model Proses Bisnis ERP, Pengendalian Manajemen dan Keunggulan Kompetitif," $J$. Akunt. DAN BISNIS J. Progr. Stud. Akunt., vol. 7, no. 1, pp. 11-22, 2021.

[9] R. Yasra and N. Alamsyah, "Analisis Pengendalian Persediaan Beras Kampung Indah 25 Kg Dengan Menggunakan Metode Peramalan Di Ud. Cahaya Keprindo," J. Tek. Ibnu Sina, vol. 3 , no. 2, pp. 117-126, 2018.

[10] L. Gao and A. G. Brink, "Whistleblowing studies in accounting research: A review of experimental studies on the determinants of whistleblowing," J. Account. Lit., vol. 38, no. April, pp. 1$13,2017$.
[11] R. W. Hilton and D. Platt, Managerial Accounting : Creating Value in Dynamic Business Environment, 10th ed. Singapore: McGraw-Hill, 2016.

[12] S. T. Schwartz and D. E. Wallin, "Behavioral implications of information systems on disclosure fraud," 2002.

[13] A. Wiranto, M. Toha, and D. Supriyadi, "Prediksi Persediaan Minimum Dan Maximum," Kolano J. Multidiscip. Sci., vol. 1, no. 01 , pp. 55-67, 2020.

[14] Syamsudin, F. M. Wajdi, and A. N. Praswati, "Desain Kemasan Makanan KUB Sukarasa di Desa Wisata Organik Sukorejo Sragen," BENEFIT J. Manag. dan Bisnis, vol. 19, no. 2, pp. 181-188, 2015. 